\title{
Leaching of PCBs and Nutrients from Soil Fertilized with Municipal Sewage Sludge
}

\author{
Magdalena Urbaniak $^{1,2} \cdot$ Ilona Gagała ${ }^{2}$ Mariusz Szewczyk ${ }^{1} \cdot$ Agnieszka Bednarek $^{1}$
}

Received: 9 December 2015/Accepted: 12 April 2016/Published online: 23 April 2016

(c) The Author(s) 2016. This article is published with open access at Springerlink.com

\begin{abstract}
Although sewage sludge is a rich source of nutrients for arable farming and soil improvement, it can also be a source of pollutants. The effects of the land application of sludge on the PCB and nutrient content of leachate were investigated using cylindrical $650 \mathrm{~mm}$ length columns filled with poor quality soil. Treatments included no fertilization (control), fertilization using a $62.5 \mathrm{t} / \mathrm{ha}$ dose (O50) of sewage sludge from the largest Polish Wastewater Treatment Plant, in Lodz, and a 62.5 $\mathrm{t} / \mathrm{ha}$ dose of sewage sludge mixed with $\mathrm{CaO}(\mathrm{O} 50 \mathrm{Ca})$. The leaching of sludge-borne PCBs and nutrients was simulated by the application of distilled water in a quantity reflecting the annual rainfall of $562.5 \mathrm{~mm}$. The obtained results demonstrate that application of sewage sludge and water simulated leaching of the most mobile chemical compounds, nitrate for example, whereas the addition of $\mathrm{CaO}$ decreased the average PCB and phosphorus concentrations in comparison to the control and O50 samples.
\end{abstract}

Keywords Sewage sludge $\cdot$ Leachate $\cdot$ PCBs $\cdot$ Nutrients

Recent years have seen increasing interest in the pathways of pollutant migration in soils fertilized with sewage sludge

Electronic supplementary material The online version of this article (doi:10.1007/s00128-016-1802-y) contains supplementary material, which is available to authorized users.

Magdalena Urbaniak

m.urbaniak@unesco.lodz.pl

1 Department of Applied Ecology, Faculty of Biology and Environmental Protection, University of Lodz, Banacha 12/16, 90-237 Lodz, Poland

2 European Regional Centre for Ecohydrology of the Polish Academy of Sciences, Tylna 3, 90-364 Lodz, Poland
(Wilson et al. 1997; Molina et al. 2000; Hesselsoe et al. 2001). The application of sewage sludge to land is widespread, as it represents a valuable source of nutrients, particularly nitrogen and phosphorus, and organic matter for arable farming and reconditioning of sandy and degraded soils (McLachlan et al. 1996; Łuczkiewicz 2006). Although sewage sludge improves soil properties, numerous studies have demonstrated that they also contain toxic organic compounds, such as polychlorinated biphenyls (PCBs) (McLachlan et al. 1996; Urbaniak et al. 2014; Wyrwicka et al. 2014), which have mutagenic, carcinogenic, immunotoxic as well as developmental and reproductive effects in living organisms (Urbaniak 2007). Despite the fact that PCBs show a strong affinity to organic matter which predispose them to be stored in the sediments (GdaniecPietryka et al. 2013) and surface layer of the soil, it has been also shown that they can be transferred deeper into the soil profile (Bi et al. 2002; Kobasić et al. 2008; Zhang et al. 2011). Hence, the continued use of such contaminated sludge for agricultural purposes can present problems associated with the risk of soil, subsurface and groundwater contamination (Bi et al. 2002). This also concerns nutrients, which despite being valuable from the perspective of agriculture, their combined application with sewage sludge may lead to health and environmental risks associated with subsurface and groundwater pollution (Kang et al. 2011). For example, as nitrates and nitrites are not retained in soils, they quickly partition to any water phase, and if not assimilated by plants, will enter surface waters through runoff. This in turn, together with phosphate leaching (Ulen and Etana, 2010; Kang et al. 2011), contributes to the acceleration of eutrophication in water reservoirs, causing deterioration of water quality and the promotion of toxic water blooms dominated by cyanobacteria (Sharpley et al. 2003; Boesch et al. 2005; Gạgała et al. 2014). 
Hence, the assessment of groundwater contamination as a result of the application of sewage sludge is an extremely important element for management of soil and groundwater resources. This paper studies the effects of land application of sewage sludge in column experiments with the aim of determining the ability of the sludge-borne PCBs and nutrients to leach from amended soil. Enzyme-linked immunosorbent assay's (ELISA) were used which allowed rapid and cost-effective analysis of PCBs in comparison to the traditional analytical approach.

\section{Materials and Methods}

Sewage sludge from the biggest Municipal Wastewater Treatment Plant in Poland located in Lodz was collected and used as fertilizer for the poor quality soil (class VI, according to the Regulation of the Council of Ministers of 12 September 2012 on the soil science and classification of land; OJ 2012 item, 1246). The used sludge were contaminated by heavy metals and organic pollutants such as dioxins and PCBs as was demonstrated in our earlier study by Urbaniak et al. (2014) and Wyrwicka et al. (2014).

The cylindrical PVC columns were used for the evaluation of PCB, total nitrogen (TN) and total phosphorus (TP) and ion $\left(\mathrm{NO}_{3}{ }^{-}, \mathrm{NO}_{2}{ }^{-}, \mathrm{NH}_{4}{ }^{+}, \mathrm{PO}_{4}{ }^{3-}\right)$ concentrations in leachate. The length of each column was $650 \mathrm{~mm}$ with an internal diameter of $100 \mathrm{~mm}$. The column experiment was conducted in 3 triplicate variants: (1) only soil (control); (2) soil fertilized with 62.5 t/ha dry weight (d.w.) sewage sludge (O50); (3) soil fertilized with 62.5 t/ha d.w. sewage sludge mixed with $40 \% \mathrm{CaO}$ d.w. (O50Ca). The experiment continued for 15 days.

Leachate samples for the analysis of PCBs, TN, TP and ions $\left(\mathrm{NO}_{3}{ }^{-}, \mathrm{NO}_{2}{ }^{-}, \mathrm{NH}_{4}{ }^{+}, \mathrm{PO}_{4}{ }^{3-}\right)$ were collected daily, starting $24 \mathrm{~h}$ after the initial application of $300 \mathrm{~mL}$ of distilled water. This procedure was repeated daily. A dose of $300 \mathrm{~mL}$ of water applied for 15 days was calculated to reflect the annual rainfall of $562.5 \mathrm{~mm}$, which is closest to the typical annual rainfall for the Lodz region (Central Poland) amounting to $572 \mathrm{~mm}$.

The PCB content of the leachate samples was analyzed using a PCB Rapid Assay kit, based on method described earlier by Wyrwicka et al. (2014). TP was analyzed by the ascorbic acid method (Greenberg et al. 1992), following digestion by Oxisolv (Merck), an oxidizing decomposition reagent, with the MV 500 Microwave Digestion System (Merck). TN was analyzed using the persulphate digestion method (HACH, 1997). The ions $\left(\mathrm{NO}_{3}{ }^{-}, \mathrm{NO}_{2}{ }^{-}, \mathrm{NH}_{4}{ }^{+}\right.$, $\mathrm{PO}_{4}{ }^{3-}$ ) were analyzed by using an ion chromatograph (Dionex Corporation, ICS-1000) according to methods described earlier by Urbaniak et al. (2012) and Gągała et al. (2014).
Fig. 1 The PCBs and nutrients concentrations in the leachate samples from control soil (control), soil amended with sewage sludge (O50) and mixture of sewage sludge and $\mathrm{CaO}$ (O50Ca) during 15-days experiment

\section{Results and Discussion}

With regard to $\mathrm{PCB}$ concentrations in groundwater only a few studies have been dedicated to this issue due to general low solubility of PCBs in water and hence, their strong tendency to be sorbed onto soil (Adeel et al. 1997; Kobasić et al. 2008). General conclusions regarding their presence in groundwater are based solely on the gross behavior of the Aroclor mixtures, and do not consider the fact that they represent a complex mix of a large number of PCB compounds that vary with regard to their solubility in water and potential for sorption and biodegradation. For example, on the basis of water solubility and $n$-octanol-water partition coefficients, the lower chlorinated congeners are not sorbed as strongly as the higher chlorinated isomers, and thus tend to leach more readily. Thus, lower chlorinated PCBs tend to have a greater presence in groundwater (Bi et al. 2002).

In the present study, PCB analysis revealed a slight increase of the average concentration from $0.40 \pm 0.15 \mu \mathrm{g} / \mathrm{L}$ in the control to $0.43 \pm 0.15 \mu \mathrm{g} / \mathrm{L}$ in leachate collected from soil treated with sewage sludge. The leachate from soil fertilized with the mixture of sewage sludge and $\mathrm{CaO}$ demonstrated a decrease in average PCB concentration in comparison to both the control and O50 samples; however, the obtained differences were not statistically relevant ( $p \geq 0.05$ ). With regard to PCB concentrations observed at individual days, the values varied between not detectable (below $0.20 \mu \mathrm{g} / \mathrm{L}$ ) to $0.70 \mu \mathrm{g} / \mathrm{L}$ in the case of the control and O50 samples, while higher concentrations were noted in the case of leachate collected from the O50Ca samples (between not detected to 0.93 $\mu \mathrm{g} / \mathrm{L}$; Fig. 1). Despite this, the average PCB concentration in the O50Ca leachate samples was the lowest of all the variants $(0.37 \pm 0.20 \mu \mathrm{g} / \mathrm{L})$.

The total amount of PCBs eluted with the applied volume of water is presented in Table 1. The lowest amount was noted for the $\mathrm{O} 50 \mathrm{Ca}(1.42 \pm 0.09 \mu \mathrm{g})$, indicating that $\mathrm{CaO}$ plays a role in the retention of $\mathrm{PCBs}$ in the soil profile, whereas the highest amount was noted for O50 $(1.54 \pm 0.13 \mu \mathrm{g})$, due to presence of sludge-borne PCBs. The used dose of PCBs with the sludge amounted to $12.30 \pm 0.43 \mu \mathrm{g}$. Thus the leaching of PCBs was minimal $(10.89 \%, 12.20 \%$ and $11.54 \%$ in the case of control, O50 and $\mathrm{O} 50 \mathrm{Ca}$ ), as these compounds exhibit a hydrophobic character and thus are not readily transported with water: the majority being retained in the soil profile. These findings confirm those of a study of the leaching of PCBs from 

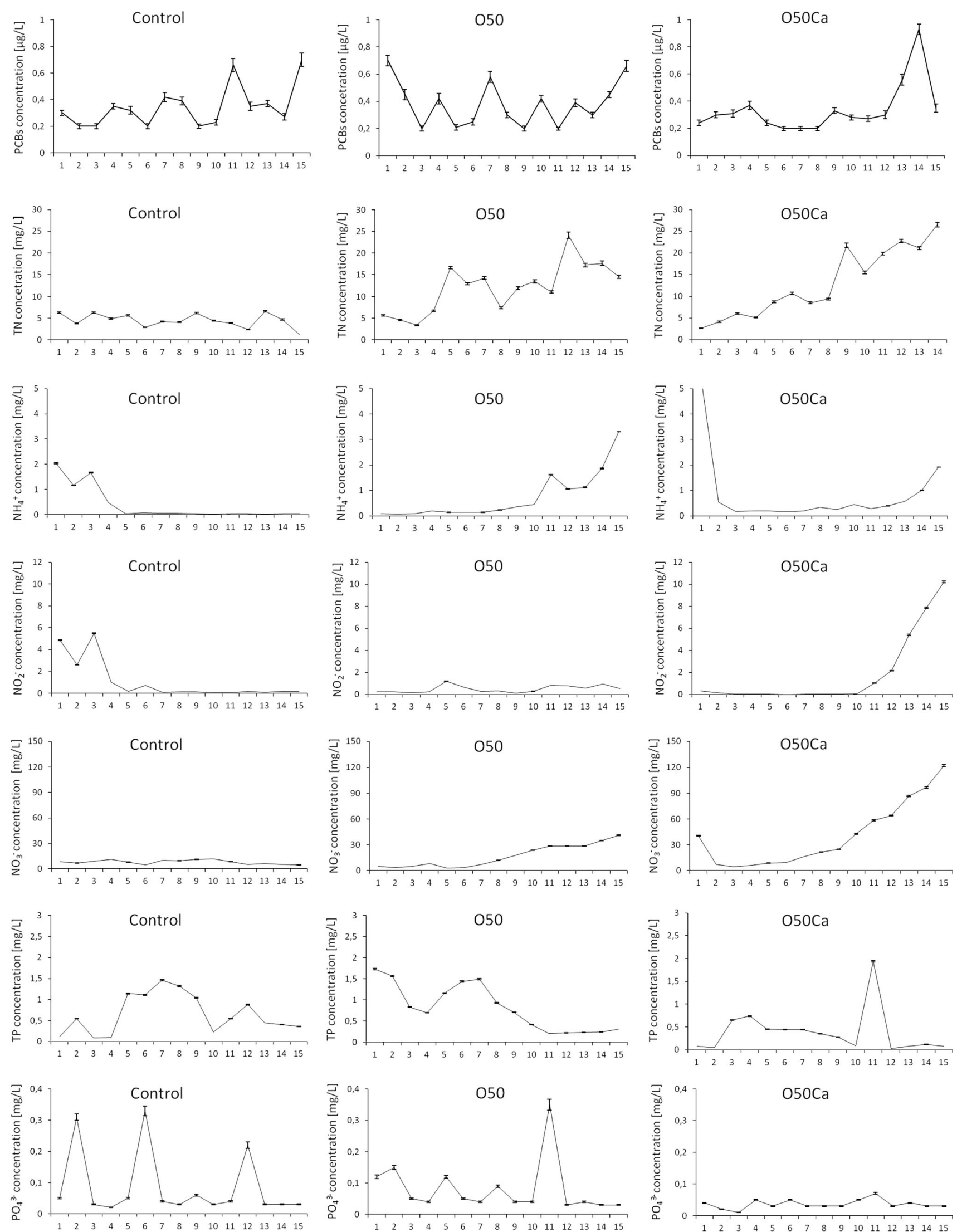
Table 1 The total amount of eluted PCBs and nutrients from control soil (control), soil amended with sewage sludge (O50) and mixture of sewage sludge and $\mathrm{CaO}(\mathrm{O} 50 \mathrm{Ca})$ during 15-days experiment

\begin{tabular}{llllllll}
\hline $\begin{array}{l}\text { Compound } \\
\text { Unit }\end{array}$ & $\begin{array}{l}\mathrm{PCB} \\
\mathrm{g}\end{array}$ & $\mathrm{TN}$ & $\begin{array}{l}\mathrm{NH}_{4}{ }^{+} \\
\mathrm{mg}\end{array}$ & $\begin{array}{l}\mathrm{NO}_{2}{ }^{-} \\
\mathrm{mg}\end{array}$ & $\begin{array}{l}\mathrm{NO}_{3}{ }^{-} \\
\mathrm{mg}\end{array}$ & $\begin{array}{l}\mathrm{TP} \\
\mathrm{mg}\end{array}$ & $\begin{array}{l}\mathrm{PO}_{4}{ }^{3-} \\
\mathrm{mg}\end{array}$ \\
\hline Control & $1.34 \pm 0.12$ & $20.90 \pm 0.56$ & $1.77 \pm 0.02$ & $4.83 \pm 0.05$ & $36.31 \pm 0.36$ & $3.05 \pm 0.03$ & $0.41 \pm 0.02$ \\
O50 & $1.54 \pm 0.13$ & $60.09 \pm 1.43$ & $3.69 \pm 0.03$ & $2.39 \pm 0.02$ & $83.27 \pm 0.76$ & $3.56 \pm 0.04$ & $0.38 \pm 0.02$ \\
O50Ca & $1.42 \pm 0.09$ & $72.01 \pm 1.31$ & $2.30 \pm 0.03$ & $8.84 \pm 0.08$ & $189.04 \pm 1.87$ & $1.92 \pm 0.02$ & $0.17 \pm 0.01$ \\
\hline
\end{tabular}

soil containing sludge and soil contaminated with hydraulic oil into groundwater by Adeel et al. (1997), which demonstrated that only a small portion of sludge-born PCB (less than $6 \%$ ) was removed from the soil by prolonged leaching.

In turn, Kobasić et al. (2008) report much lower leaching $(0.34 \%)$ of the sum of seven indicator PCBs around a damaged capacitor, with the majority of the PCB congeners washed away in the summer due to higher temperatures and heavier rainfall. Despite this, the authors indicate the presence of much higher $\mathrm{PCB}$ concentrations than those obtained in the present study, ranging from 1.60 to $22.25 \mu \mathrm{g} / \mathrm{L}$. The differences in the obtained portions of leached PCBs could mostly be attributed to the fact that Kobasić et al. (2008) analyzed only seven indicator congeners, whereas the present study addresses total PCB concentration ( $\Sigma 209$ PCB congeners), including a variety of congeners of diverse solubility. In consequence, the higher rate of eluted PCBs observed in our case may be attributed to the lower chlorinated and thus less hydrophobic congeners. In addition, the higher concentrations of PCBs observed by Kobasić et al. (2008) could be attributed to their choice of analytical technology, i.e. instrumental chromatographic analysis, as the present study is based on an ELISA test kit: some ELISA readings can be underestimated in comparison to conventional chromatographic analysis (Nording et al. 2006; Tsutsumi et al. 2006) resulting in the higher concentration noted by the authors. Kobasić et al. (2008) collected leachate samples over a 1 -year period following precipitation events, and documented no accelerated or time-restricted washing of PCBs from soil profiles similar to the present study.

The relatively similar concentrations (Fig. 1) and amounts of eluted PCBs (Table 1) observed in the control, $\mathrm{O} 50$ and $\mathrm{O} 50 \mathrm{Ca}$ samples may be the effect of releasing some portions of PCBs from the used cylindrical PVC columns. As it is reported in the UNEP guidelines (UNEP, 1999) PVC materials act as source PCBs in the environment. The obtained results also demonstrate the role of $\mathrm{CaO}$ in diminishing PCB leaching from soil fertilized with sewage sludge. This can be an effect of PCB dechlorination in the presence of $\mathrm{CaO}$ as it was demonstrated by Mitoma et al. (2013).
The differences in the obtained results can be also related to the permeability, porosity, homogeneity, texture, and mineralogy of the soil, which affect the desorbability of PCBs. Haque and Schmedding (1976) report that PCB sorption in different sorbents (sand, soil, clay and humic acids) occurs in order of reducing chlorination, i.e. hexa- $>$ tetra- $>$ dichlorobiphenyls. Other studies note that sorption of PCB in soil increases with increasing soil organic carbon content (Urbaniak 2007; Zhang et al. 2011). In consequence, as the sorption reaction influences the transport and fate of PCBs and their partitioning in different compartments of the soil-groundwater system, a simple comparison of our findings with other data is not possible.

In the case of $\mathrm{TN}$, the maximum values were noted in leachate eluted from soil fertilized with the sewage sludge mixed with $\mathrm{CaO}$ (up to $36.50 \mathrm{mg} / \mathrm{L}$ ). The same dose used without $\mathrm{CaO}$ caused lower TN concentrations (maximum $24.10 \mathrm{mg} / \mathrm{L}$; Fig. 1). Similar results were obtained in the case of the total amount of eluted TN (Fig. 1). Therefore significant differences in TN concentration between the control and $\mathrm{O} 50$, and between the control and $\mathrm{O} 50 \mathrm{Ca}$ leachate samples were noted $(p \geq 0.05)$, while there were no statistically relevant differences observed in the case of $\mathrm{O} 50$ and $\mathrm{O} 50 \mathrm{Ca}(p \geq 0.05)$. These values are higher than those noted in previous studies. For example, Duan et al. (2010) report the concentration of TN in leachate from a wastewater land application system to be significantly lower than $10 \mathrm{mg} / \mathrm{L}$, therefore demonstrating no potential nitrogen contamination for groundwater. In our case, the concentration of TN exceeded $10 \mathrm{mg} / \mathrm{L}$ in 10 and 8 samples of $\mathrm{O} 50$ and $\mathrm{O} 50 \mathrm{Ca}$, respectively, with the higher average value noted for O50Ca (Fig. 1). In contrast, concentrations above $10 \mathrm{mg} / \mathrm{L}$ were not observed for the control samples.

With regard to the nitrogen ions, the obtained results demonstrated the enhanced concentrations of nitrate, reaching maximum values of $11.30,40.94$ and $122.03 \mathrm{mg} / \mathrm{L}$ in control, O50 and O50Ca samples, respectively; whereas nitrite and ammonium demonstrated values which were several times lower (Fig. 1). Furthermore, all the ions showed different concentrations over time: ammonium demonstrated increased values at the beginning of the experiment in the control samples, while in $\mathrm{O} 50$ and $\mathrm{O} 50 \mathrm{Ca}$, the highest concentrations occurred at the end of the 
experiment. The exception was the O50Ca sample, in which the highest noted ammonium concentration $(5.27 \mathrm{mg} / \mathrm{L})$ occured on Day 1 of the experiment. Nitrite concentrations showed a similar trend to ammonium, with elevated concentrations noted for $\mathrm{O} 50 \mathrm{Ca}$ samples at the end of the experiment. O50 samples demonstrated the highest values one-third-way through the experiment, i.e. on the 5th and 6th days, and then at the end of the test period, whereas the control samples revealed the greatest values at the beginning of the experiment (Fig. 1). In turn, fluctual changes were observed in nitrate concentration, with elevated values noted at the beginning, until the 4th day, and in the middle of the experiment, on the 9th and 10th days, with lower concentrations interspersed between them (Fig. 1). Leachate from O50 showed increased nitrite values, above $10 \mathrm{mg} / \mathrm{L}$, starting from the 8th day of the experiment. However, leachate collected from $050 \mathrm{Ca}$, showed high concentrations at the 1st day $(40.38 \mathrm{mg} / \mathrm{L})$, followed by a rapid decline (below the $10 \mathrm{mg} / \mathrm{L}$ ) during the next 5 days, and then increasing again from the 7th day, with concentrations ranging from 16.41 up to $122.03 \mathrm{mg} / \mathrm{L}$ on the last day (Fig. 1).

In relation to the obtained high concentrations of nitrate, it needs to be emphasized that this form of nitrogen is the most mobile in soil and hence the most problematic potential pollutant of waters, being associated with e.g. methemoglobinemia and carcinogenic and mutagenic changes observed mainly in the digestive system. Regarding these negative health effects, the World Health Organization has set the limit for nitrate in potable water at $50 \mathrm{mg} / \mathrm{L}$ (Drinking Water Directive 98/83/EC). The same limit value was also established for groundwater (Nitrates Directive 91/676/ EEC), while EPA's sets the maximum contaminant level for nitrate at lower level of $10 \mathrm{mg} / \mathrm{L}$. The obtained results exceed these allowable limits of $50 \mathrm{mg} / \mathrm{L}$ only in the case of O50Ca reaching $122.03 \mathrm{mg} / \mathrm{L}$ at the highest, while $10 \mathrm{mg} / \mathrm{L}$ limit was exceeded also in the case of O50 reaching $40.94 \mathrm{mg} / \mathrm{L}$ at the highest (Fig. 1). The high mobility of nitrate is also observed in the amount of eluted compounds, which reached $36.31 \pm 0.36, \quad 83.27 \pm 0.76 \quad$ and $189.04 \pm 1.87 \mathrm{mg}$ in control, O50 and O50Ca, respectively, whereas nitrite and ammonium achieved maximum values of $8.84 \pm 0.08 \quad(\mathrm{O} 50 \mathrm{Ca})$ and $3.69 \pm 0.03 \mathrm{mg} \quad(\mathrm{O} 50$; Table 1). This is a clear indication of the problem associated with applying sewage sludge to fields, resulting in enhanced nitrate leaching and a greater risk to groundwater.

In the case of phosphorus, the present study showed that application of sewage sludge at a dose of $62.5 \mathrm{t} / \mathrm{ha}$ resulted in a $25 \%$ increase in average TP concentration, whereas application of mixture of sewage sludge and $\mathrm{CaO}$ resulted in a $40 \%$ decrease of average TP concentration (Fig. 1). Similarly, while the highest total amount of the washed TP was demonstrated in the case of O50, this value observed in leachate from the soil amended with sewage sludge and $\mathrm{CaO}$ was 1.6 times lower than that of the control soil, however the obtained differences were not statistically different $(p \geq 0.05)$ (Fig. 1). Also, in the case of orthophosphate, $\mathrm{CaO}$ was demonstrated to play a decreasing role (Fig. 1; Table 1). The $\mathrm{Ca}$ in soil reacts with phosphate and leads to the formation of dibasic calcium phosphate dihydrate, octocalcium phosphate, and hydroxyapatite. The formation of each product results in a decrease in the solubility and availability of orthophosphate, thus diminishing its concentration in the soil leachate samples amended with the mixture of sewage sludge and $\mathrm{CaO}$. Hence, the application of such mixtures seems to be an effective way to minimize the risk related to sewage sludge usage.

To conclude, our findings show that the application of sewage sludge and water increase leaching of nitrate, as well as other highly mobile chemical compounds, with the highest rate observed in the case of sewage sludge and $\mathrm{CaO}$ mixture. On the other hand, compounds with high affinity to organic matter such as PCBs, TP and orthophosphate, decreased as an effect of $\mathrm{CaO}$ addition, demonstrate the potential of the use of $\mathrm{CaO}$ as a means of reducing the risk of the presence of the above compounds in groundwater.

Acknowledgments The project was funded by the National Science Centre granted on the basis of the Decision Number DEC-2013/09/D/ ST10/04043. The study was also carried out as a part of the following projects: "Innovative recourses and effective methods of safety improvement and durability of buildings and transport infrastructure in the sustainable development" (POIG.01.01.02-10-106/09) financed by the European Union from the European Fund of Regional Development based on the Operational Program of the Innovative Economy, "Development of model geofibrous, biodegradable, biological deposits for recultivation nitrogen and phosphorus in threatened areas of agricultural landscape (N R14 0061 06/2009 GEOWŁÓKNA) supported by the National Centre for Research and Development and "Microbial activators in denitrifying deposits used for the treatment of nitrate pollution for the implementation of the Water Framework Directive and the Nitrates Directive" (PBS1/A8/ 2012 MIKRAZO) financed by the National Centre for Research and Development.

Open Access This article is distributed under the terms of the Creative Commons Attribution 4.0 International License (http://creati vecommons.org/licenses/by/4.0/), which permits unrestricted use, distribution, and reproduction in any medium, provided you give appropriate credit to the original author(s) and the source, provide a link to the Creative Commons license, and indicate if changes were made.

\section{References}

Adeel Z, Luthy RG, Dzombak DA, Roy SB, Smith JR (1997) Leaching of PCB compounds from untreated and biotreated sludge-soil mixtures. J Contam Hydrol 28:289-309

Bi X, Chu S, Meng Q, Xu X (2002) Movemnt and retention of polychlorinated biphenyls in a paddy field of WenTai are in China. Agric Ecosyst Environ 89:241-252 
Boesch D, Hecky R, O'Melia C, Schindler D, Seitzinger S (2005) Expert evaluation of the eutrophication of the seas surrounding Sweden. SNV Report, 29-09-2005, p 54

Duan R, Fedler CB, Sheppard CD (2010) Nitrogen leaching losses from a wastewater land application system. Water Environ Res 82(3):227-235

Gągała I, Izydorczyk K, Jurczak T, Pawełczyk J, Dziadek J, WojtalFrankiewicz A, Jóźwik A, Jaskulska A, Mankiewicz-Boczek J (2014) Role of environmental factors and toxic genotypes in the regulation of microcystins-producing cyanobacterial blooms. Microb Ecol 67:465-479

Gdaniec-Pietryka M, Mechlińska A, Wolska L, Namieśnik J (2013) Remobilization of polychlorinated biphenyls from sediment and its consequences for their transport in river waters. Environ Monit Assess 185(5):4449-4459

Greenberg AE, Clesceri LS, Eaton AD (1992) Standard methods for the examination of water and wastewater. American Public Health Association, Washington

HACH (1997) Water analysis handbook. Hach Company, Loveland

Haque R, Schmedding D (1976) Studies on the adsorption of selected polychlorinated biphenyl isomers on several surfaces. J Environ Sci Health B 11(2):129-137

Hesselsoe M, Jensen D, Skals K, Olesen T, Moldrup P, Roslev P, Mortensen GK, Henriksen K (2001) Degradation of 4-nonylphenol in homogeneous and nonhomogeneous mixtures of soil and sewage sludge. Environ Sci Technol 35:3695-3700

Kang J, Amoozegar A, Hesterberg D, Osmond DL (2011) Phosphorus leaching in a sandy soil as affected by organic and inorganic fertlizer sources. Geoderma 161:194-201

Kobasić VH, Picer M, Picer N, Calic V (2008) Transport of PCBs with leachate water from contaminated soil. Chemosphere 73:143-148

Łuczkiewicz A (2006) Soil and groundwater contamination as result of sewage sludge land application. Pol $\mathrm{J}$ Environ Stud 15(6):869-876

McLachlan MS, Horstmann M, Hinkel M (1996) Polychlorinated dibenzo- $p$-dioxins and dibenzofurans in sewage sludge: sources and fate following sludge application to land. Sci Total Environ 185:109-123

Mitoma Y, Mallampati SR, Muyata H, Kadeka M (2013) Decomposition of polychlorinated biphenyls in soil with a dispersion mixture of metallic calcium and calcium oxide. Arch Environ Cotam Toxic 64:180-186
Molina L, Diaz-Ferrero J, Coll M, Martı R, Broto-Puig F, Comellas L (2000) Study of evolution of PCDD/F in sewage sludgeamended soils for land restoration purposes. Chemosphere 40:1173-1178

Nording M, Nichkova M, Spinnel E, Persson Y, Gee ShJ, Hammock BD, Haglund P (2006) Rapid screening of dioxin-contaminated soil by accelerated solvent extraction/purification followed immunochemical detection. Anal Bioanal Chem 385:357-366

Sharpley AN, Weld JL, Beegle DB, Kleinman PJA, Gburek WL, Moore PA, Millins G (2003) Development of phosphorus indices for nutrient management planning strategies in the U.S. J Soil Water Conserv 58(3):137-152

Tsutsumi T, Amakura Y, Okuyama A, Tanioka Y, Sakata K, Sasaki K, Maitani T (2006) Application of an ELISA for PCB 118 to the screening of dioxin-like PCBs in retail fish. Chemosphere 65:467-473

Ulen B, Etana A (2010) Risk of phosphorus leaching from low input grassland areas. Geoderma 158:359-365

UNEP (1999) Guidelines for the identification of PCBs and materials containing PCBs. First Issue, August 1999

Urbaniak M (2007) Polychlorinated biphenyls (PCBs): sources, distribution and transformation in environment-literature review. Acta Toxic 15(2):83-93

Urbaniak M, Skowron A, Zieliński M, Zalewski M (2012) Hydrological and environmental conditions as key drivers for spatial and seasonal changes in PCDD/PCDF concentrations, transport and deposition along urban cascade reservoirs. Chemosphere 88:1358-1367

Urbaniak M, Wyrwicka A, Serwecińska L, Zieliński M, Tołoczko W (2014) Impact of sludge originated PCDDs/PCDFs on soil contamination and Salix sp. metabolism. In: Proceedings of the 14th international multidisciplinary scientific geo-conference \& EXOP SGEM2014. STEF92 Technology Ltd, 169-174

Wilson SC, Alcock RE, Sewart AP, Jones KC (1997) Persistence of organic contaminants in sewage sludge-amended soil, a field experiment. J Environ Qual 26:1467-1477

Wyrwicka A, Steffani S, Urbaniak M (2014) The effect of PCBcontaminated sewage sludge and sediment on metabolism of cucumber plants (Cucumis sativus L.). Ecohydrol Hydrobiol. doi:10.1016/j.ecohyd.2014.01.003

Zhang H, Li X, Luo Y, Li Q (2011) Depth distribution of polychlorinated biphenyls in soils of the Yangtze River Delta region, China. Geoderma 160:408-413 